Cell Physiol Biochem 1996;6:1-2

\title{
Contents, Vol. 6, 1996
}

Editorial

Burckhardt, G. (Göttingen) A Tribute to Karl Julius Ullrich, Prof. Dr. med. Dr. h.c. 3

Reviews

Dantzler, W.H. (Tucson, Ariz.) Comparative Aspects of Renal Organic Anion

Transport 28

Pritchard, J.B.; Miller, D.S. (Research Triangle Park, N.C.) Intracellular

Compartmentation of Organic Anions and Cations during Renal Secretion 50

Wright, S.H. (Tucson, Ariz.)

Characterization of Renal Brush-Border and Basolateral Membrane Transporters for Organic Cations

112

Original Paper

Basoglu, C; Burckhardt, G.; Wolff, N.A. (Göttingen)

Micromolar Concentrations of Bromosulfophthalein Affect Transport of D-Glucose, LAlanine and p-Aminohippurate in Rat Renal Brush-Border Membranes

Brühl, B.; Tripier, D.; Jouvenal, K.; Guckes, S.; Ottallah-Kolac, M.; Petzinger, E. (Giessen/Frankfurt)

Microsequencing of Organic Anion-Binding Proteins from Basolateral Plasma

Membranes in Hepatocytes after Photoaffinity Labelling with Bumetanide and 7 , 7-

Azotaurocholate

13

Faber, S.; Lang, H.-J.; Hropot, M.: Schölkens, B.A.; Mutschler, E. (Frankfurt) A Novel Screening Assay of the Na+-Dependent C1-/HC03 Exchanger (NCBE) and Its Inhibitors

39

KAHGER

E-Mail karger@karger.ch Fax + 41613061234 http://www. karger. ch

(C) 1996 S. Karger AG, Basel

The list of contents is available at: http://www.karger.ch/joumals/cpb/cpbcont.htm

Roch-Ramel, F.; Guisan, B. Jaeger, Ph.; Diezi, J. (Lausanne/Bern)

Transport of Urate and Other Organic Anions by Anion Exchange in Human Renal Brush-Border Membrane Vesicles

60 
Stachon, A.; Schlatter, E.; Hohage, H. (Münster)

Dynamic Monitoring of Organic Cation Transport Processes by Fluorescence

Measurements in LLC-PKi Cells

72

Steffgen, J.;

Ehrhart-Bornstein, M.; Bähr, V.; Herkommer, B.; Sippell, W.G.; Güse-Behling, H.;

Franz, H.E.; Scherbaum, W.A.; Bornstein, S.R. (Ulm/Berlin/Kiel)

Evidence for the Involvement of an Anion Exchanger in Cortisol Release from Bovine Adrenocortical Cells

82

Thévenod, F.; Striessnig, J.;

Haase, W.; Anderie, I.;

Hildebrandt, J.-P.;

de Jonge, H.R.; Schulz, I.

(Homburg/Innsbruck/Frankfurt/

Rotterdam)

Functional Relationship between a 65-kD mdrl P-Glycoprotein and ATP-Activated

Chloride Conductance in Pancreatic Zymogen Granule Membranes

91

Wagner, C.A.; Raber, G; Waldegger, S.; Osswald, H.; Biber, J.; Murer, H.; Busch, A.E.;

Lang, F. (Tübingen/Zürich)

Regulation of the Human Brush Border Na+/Phosphate Cotransporter (NaPi-3)

Expressed in Xenopus Oocytes by Intracellular Calcium and Protein Kinase C

105

Zdebik, A.; Hug, M.J.; Greger, R. (Freiburg)

Low Concentrations of Carbachol Induce Oscillations of Membrane Voltage towards E $\alpha$ but Not the Nernst Potential for Nonselective Cation Channels in Rat Pancreatic Acinar Cells

123

Announcement

128

2

Contents 